transition, in a sense, sent us back to where we were tens of thousand of years ago, before the invention of agriculture, when many (most?) humans were living and migrating along coastlines, relying on shellfish and, starting from Africa, gradually reaching islands as far flung as Tasmania and Tierra del Fuego ${ }^{3}$.

These migrations, which brought our African ancestors to Europe and Asia, and thence to Australia and Oceania, and to the Americas, were in most cases followed by migrations inland, driven by hunting of larger animals, and later by agriculture. And interestingly, there is documentation, also from Britain, of a change in diet some 5,200 years ago, at the start of the Neolithic and of British agriculture, from marine animals to inland animals and plants ${ }^{4}$.

The transition from eating freshwater fish to eating marine fish, documented by Barrett et al., is thus part of a secondary transition. Marine fisheries catches are declining worldwide ${ }^{5}$, and the global demand for fish is increasing. So will another transition back to freshwater fish and inland species occur? Or will we be able to 'row' even more, and maintain our present level of marine fish consumption?

Daniel Pauly is at the Fisheries Centre, Lower Mall Research Station, 2259 Lower Mall, University of British Columbia, Vancouver, British Columbia V6T 1Z4, Canada. e-mail:d.pauly@fisheries.ubc.ca

1. Lacey, R. \& Danziger, D. The Year 1000: What Life Was Like at the Turn of the First Millennium (Little, Brown, New York, 1999).

2. Barrett, J. H., Locker, A. M. \& Roberts, C. M. Proc. R. Soc. Lond. B 271, 2417-2421 (2004). See also Electronic Appendix A: "Summary information and reference for the fish bone assemblages surveyed."
3. Erlandson, J. M. in The First Americans: The Pleistocene Colonization of the New World (ed. Jablonski, N. G.) 59-92, Mem. Calif. Acad. Sci. No. 27 (Calif. Acad. Sci., San Francisco, 2002)

4. http://news.nationalgeographic.com/news/ 2003/09/0924_030924_neolithicdiet.html\#main (accessed 20 September 2004)

5. Watson, R. \& Pauly, D. Nature 414, 534-536 (2001).

\title{
Palaeoclimate
}

\section{A balmy Arctic}

\author{
Christopher J. Poulsen
}

Analyses of sediments retrieved from a drifting ice island suggest that the Arctic Ocean may have been ice free and as warm as $15^{\circ} \mathrm{C}$ about 70 million years ago. Therein is a challenge for climate models.

V arious lines of evidence show that Earth's climate was much warmer during the Cretaceous period than it is today. Yet that evidence - fossil plants and animals, sedimentary features and geochemical indicators - is sparse, spotty and often inexact, making the magnitude and distribution of Cretaceous temperatures highly uncertain. In a testament to quality over quantity, Jenkyns et al. ${ }^{1}$ (page 888 of this issue) have produced a single new datum from one of the coldest spots on Earth's surface: their work clarifies the nature of extreme warmth in the Cretaceous, and reveals that the past was radically different from the present.

Ironically, Jenkyns and colleagues' evidence for a warm Arctic climate was retrieved by drilling through an ice island drifting over the Alpha Ridge, one of three submarine ridges that divide the Arctic sea floor (see the map on page 889). Sediments deposited on the modern Arctic sea floor are oxidized, rich in silt and sand, and have only sparse evidence of planktonic life: with nearly 3 metres of sea ice capping its surface, the Arctic Ocean is not a hospitable environment for most organisms. In sharp contrast,

Planetary science

\section{Anill solar wind}

On 1 November last year, my father phoned me from Tenerife to ask why he wasn't able to receive the BBC World Service. His concern was not at missing the news bulletins, but rather at what might have happened to his beloved transmitters at Rampisham in the south of England or on Ascension Island in the mid-Atlantic (my father is a chartered electrical engineer). In fact, it was unusually high sunspot activity that was upsetting his reception. Elsewhere in this issue, Daniel Baker and colleagues report exactly how dramatic were the effects on Earth's atmosphere of the solar winds from those sunspots (Nature 432, 878-881; 2004).

Short-wave radio signals are transmitted around the world by refraction and reflection from a layer of ions in the atmosphere; this Appleton layer (named after Edward Appleton, who discovered it in 1926) lies between 150 and $1,000 \mathrm{~km}$ above Earth's surface. Higher still, at 3,000-6,000 km and 20,000-25,000 km above the Equator, are the Van Allen belts two toroidal regions of high-energy ions, mainly electrons and protons, trapped by Earth's magnetic field. The relatively calm region between the belts is a future orbit of choice for artificial satellites. The inner edge of the outer belt also corresponds to the limit of Earth's plasmasphere, which is dense with ions.

Around Halloween in 2003, two spacecraft - the Solar Anomalous and Magnetospheric Particle Explorer (SAMPEX) and the Imager for Magnetopause-to-Aurora Global

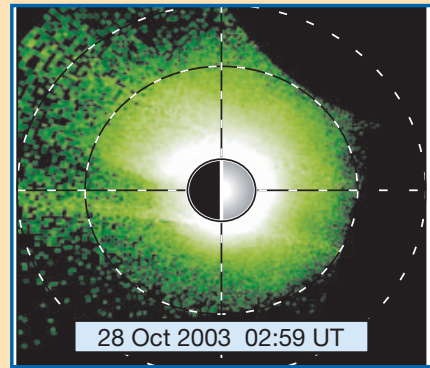

Exploration (IMAGE) — detected massive distortions in the Van Allen belts and the plasmasphere as the solar winds hit. The gap between the belts was obliterated throughout November, as electrons were 'blown' through into the inner belt, increasing its electron density 50-fold - a situation that has persisted ever since. The effect on the plasmasphere (pictured) was even more dramatic, if shorter-lived. On 28 October, it extended as usual to about 19,000 km above Earth's surface; by 31 0ctober it had contracted to $6,000 \mathrm{~km}$, and in places to as low as $3,000 \mathrm{~km}$,

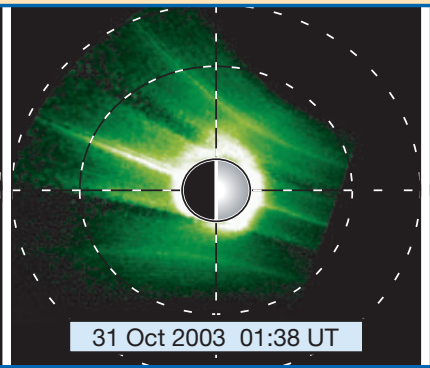

returning to close to normal within a few days.

These changes greatly reduced Earth's natural shields against solar and cosmic radiation. Contact was lost with satellites; astronauts on the International Space Station took cover in a heavily shielded service module; the US Federal Aviation Administration issued its first-ever radiation alert to passengers flying above 7,500 m; and the power system in Malmö, Sweden, failed.

Small wonder, then, that the Appleton layer could not relay the World Service to my father in the Canaries. Christopher Surridge






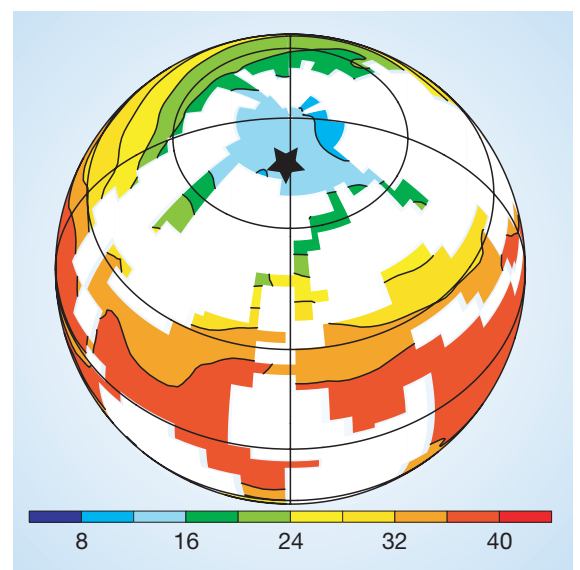

Figure 1 Average annual sea surface temperature for the Cretaceous predicted by an ocean-atmosphere climate model. Units are ${ }^{\circ} \mathrm{C}$, and the white areas indicate land masses. Using data from the Alpha Ridge (star), Jenkyns et al. ${ }^{1}$ conclude that during the Late and Middle Cretaceous, seawater temperatures in the Arctic were $15{ }^{\circ} \mathrm{C}$ or more. Climate models cannot simulate such warm conditions without incorporating very high $\mathrm{CO}_{2}$ levels that exceed the estimates of $\mathrm{CO}_{2}$ at that time'. In this example, Arctic seawater temperature is nearly $15^{\circ} \mathrm{C}$. But the model concentration of atmospheric $\mathrm{CO}_{2}$ required is 7,100 p.p.m.v., 20 times present levels, and 3-6 times larger than the estimated levels for the Cretaceous.

the Late Cretaceous sediment from the Alpha Ridge consists of an ooze that is rich in diatoms (unicellular algae) and black mud that contains woody fragments, leaf cuticles, spores and pollen. The sediments are also notable for what they do not contain dropstones, the non-marine debris that fall from the base of icebergs. All in all, these sediments were evidently the product of fertile, ice-free marine waters.

Although the sedimentary evidence from the Arctic marine cores is suggestive of warm, ice-free conditions, it is a very imprecise thermometer. For this reason, palaeooceanographers often draw on geochemical tools, such as the ratio of oxygen isotopes in carbonate shells from marine microorganisms, that can provide precise estimates of seawater temperature. Because of the absence of carbonate in Arctic Cretaceous sediments, traditional methods could not be used. So Jenkyns et al. ${ }^{1}$ turned to a novel method (called $\mathrm{TEX}_{86}$ ) for quantifying sea surface temperature. They examined the composition of lipids in the membranes of Crenarchaeota, floating marine microorganisms that range in size from 0.2 to 2.0 micrometres, and which have been found in sediments up to 112 million years old.

Earlier work showed that the composition of organic compounds in the membranes of modern Crenarchaeota is highly correlated with seawater temperature and may well be a biological adaptation to the thermal state of the marine environment ${ }^{2}$. The $\mathrm{TEX}_{86}$ method has previously been tested on Cretaceous sediments from low latitudes, and the results are in good agreement with estimates of seawater temperature using oxygen isotopes ${ }^{3}$.

Applying this new geochemical tool to 70-million-year-old organic material from the Alpha Ridge, Jenkyns et al. ${ }^{1}$ calculate that the average sea surface temperature was $15{ }^{\circ} \mathrm{C}$. Sea water of similar temperature is presently found off (for example) Maryland and France, at latitudes between $35^{\circ} \mathrm{N}$ and $45^{\circ} \mathrm{N}$. For a region blanketed in darkness for half of the year, the Arctic Ocean was astoundingly warm. It may have been even warmer earlier in the Cretaceous: proxy evidence indicates that the climate had been slowly cooling for nearly 20 million years. Although astounding, the new estimate of Arctic seawater temperature is not without precedent. Fossil evidence of the tropical breadfruit tree Artocarpus dicksoni and of champsosaurs, extinct crocodile-like reptiles, has been found in sediments from the high Canadian Arctic dating to the middle Cretaceous (90-100 million years ago $)^{4,5}$.

Why was the Cretaceous so warm? The most likely explanation is high concentrations of atmospheric carbon dioxide that resulted from high rates of volcanic outgassing. Atmospheric $\mathrm{CO}_{2}$ is the primary greenhouse gas that is believed to have contributed to global warming since the beginning of the industrial revolution. In the Cretaceous, $\mathrm{CO}_{2}$ levels were probably three to six times those of today, giving rise to a supergreenhouse climate. Yet model simulations ${ }^{6,7}$ of climate during the Cretaceous, using these estimates of past $\mathrm{CO}_{2}$ levels, produce Arctic Ocean temperatures of $2-6{ }^{\circ} \mathrm{C}$, much lower than the estimates of Jenkyns et al. ${ }^{1}$.

Although it is possible that these estimates of past $\mathrm{CO}_{2}$ are too low, problems still remain for the climate models. Specifying higher $\mathrm{CO}_{2}$ levels warms the polar regions (Fig. 1). But it also leads to very high temperatures at low latitude - temperatures that exceed the estimated values using proxy methods and approach the tolerance level of organisms ${ }^{8}$.

Why do simulations of the Cretaceous climate predict polar temperatures that are too cold and Equator-to-pole temperature gradients that are too large? The solution to the problem may lurk in the climate models themselves. Attempts have been made to solve it by incorporating the effects of ocean heat transport, stratospheric clouds, ocean passageways, and vegetation. The result, however, has been only incremental improvements. Climate models still do an inadequate job of simulating the extreme warmth of a past greenhouse world - a troubling proposition for predictions of a future greenhouse world.

Christopher J. Poulsen is in the Department of Geological Sciences, University of Michigan,

Ann Arbor, Michigan 48109, USA.

e-mail:poulsen@umich.edu

1. Jenkyns, H. C., Forster, A., Schouten, S. \& Sinninghe Damsté, J. S. Nature 432, 888-892 (2004).

2. Schouten, S., Hopmans, E., Schefuß, E. \& Sinninghe Damsté,

J. S. Earth Planet. Sci. Lett. 204, 265-274 (2002).

3. Schouten, S. et al. Geology 31, 1069-1072 (2003).

4. Tarduno, J. et al. Science 282, 2241-2244 (1998).

5. Morton, J. Fruits of Warm Climates (Creative Resources Systems, Miami, 1987).

6. Poulsen, C., Barron, E., Peterson, W. \& Wilson, P. Paleoceanography 14, 679-697 (1999).

7. Otto-Bliesner, B., Brady, E. \& Shields, C. J. Geophys. Res. 107, 10.1029/2001JD000821 (2002).

8. Barron, E. Earth Sci. Rev. 19, 305-338 (1983)

9. Bice, K. \& Norris, R. Paleoceanography 17,

10.1029/2002PA000778 (2002).

Cell biology

\section{Popping out of the nucleus}

\section{André Hoelz and Günter Blobel}

Previous structural snapshots have provided insight into how proteins are imported into the cell nucleus. The structure of an export complex now completes the molecular picture of the nuclear transport cycle.

A notable stage in evolution was the compartmentalization of cells, producing the eukaryotic cell - the cell type found in organisms from fungi to humans. During this process, the genetic information became enclosed inside a nucleus, spatially separated from the rest of the cell. The only way that macromolecules can be transported into and out of the nucleus is through large protein assemblies termed nuclear pore complexes, which are located in circular openings in the nuclear membrane, or 'envelope'. Mobile proteins that ferry cargo are also required for import and export, as is another protein, Ran, whose conformational state alters the affinity of the carriers for their cargo. On page 872 of this issue, Matsuura and Stewart ${ }^{1}$ reveal the structure of one nuclear export protein complex. Comparing this snapshot with structures of nuclear import complexes sheds light on why Ran has different roles depending on whether cargo is being directed into or out of the nucleus.

Nuclear transport is mediated by short sequence elements in cargo molecules: cargo carrying a nuclear localization sequence (NLS) is imported, whereas a nuclear export 